\title{
Twenty-four hour efficacy with preservative free tafluprost compared with latanoprost in patients with primary open angle glaucoma or ocular hypertension
}

\author{
Anastasios G P Konstas, ${ }^{1}$ Luciano Quaranta, ${ }^{2}$ Andreas Katsanos, ${ }^{3}$ Ivano Riva, ${ }^{2}$ \\ James C Tsai, ${ }^{4}$ Theodoros Giannopoulos, ${ }^{1}$ Irini C Voudouragkaki, ${ }^{1}$ Eleni Paschalinou, ${ }^{1}$ \\ Irene Floriani, ${ }^{5}$ Anna-Bettina Haidich ${ }^{6}$
}

${ }^{1}$ Glaucoma Unit, 1st University Department of Ophthalmology, Aristotle University, AHEPA Hospital, Thessaloniki, Greece ${ }^{2}$ Centre for the Study of Glaucoma, University of Brescia, Brescia, Italy ${ }^{3}$ Ophthalmology Department, University of Ioannina, Ioannina, Greece ${ }^{4}$ Department of Ophthalmology and Visual Science, Yale Eye Center, Yale University School of Medicine, New Haven, Connecticut, USA

IRCCS Istituto di Ricerche Farmacologiche Mario Negri, Milan, Italy

${ }^{6}$ Department of Hygiene, Aristotle University, Thessaloniki, Greece

Correspondence to Professor A G P Konstas, Glaucoma Unit, 1st University Department of Ophthalmology, Aristotle University, AHEPA Hospital, 1 Kyriakidi Street, Thessaloniki 546 36, Greece; konstas@med.auth.gr

Received 24 December 2012 Revised 12 March 2013 Accepted 7 April 2013
To cite: Konstas AGP, Quaranta L, Katsanos A, et al. Br J Ophthalmol Published Online First: [please include Day Month Year] doi:10.1136/

bjophthalmol-2012-303026

\section{ABSTRACT}

Aim To compare $24 \mathrm{~h}$ intraocular pressure (IOP) control obtained with preservative free (PF) tafluprost $0.0015 \%$ versus branded preservative containing latanoprost $0.005 \%$ administered as first choice monotherapy in patients with primary open angle glaucoma (POAG) or ocular hypertension (OHT).

Methods This prospective, observer-masked, crossover study included consecutive newly diagnosed patients with POAG or OHT, and baseline IOP between 24 and $33 \mathrm{~mm} \mathrm{Hg}$. Qualifying patients underwent baseline untreated $24 \mathrm{~h} \mathrm{IOP}$ monitoring in habitual positions, with Goldmann tonometry at times 10:00, 14:00, 18:00 and 22:00, and Perkins supine tonometry at times 02:00 and 06:00. They were then randomised to either latanoprost or tafluprost, administered in the evening, for 3 months and then switched to the opposite therapy for another 3 months. $24 \mathrm{~h}$ monitoring was repeated at the end of each treatment period.

Results 38 patients completed the study. Mean untreated $24 \mathrm{~h}$ IOP (24.9 mm Hg) was significantly reduced with both prostaglandins $(p<0.001)$. Tafluprost demonstrated similar mean $24 \mathrm{~h}$ efficacy compared with latanoprost (17.8 vs $17.7 \mathrm{~mm} \mathrm{Hg} ; \mathrm{p}=0.417$ ). Latanoprost demonstrated significantly better $24 \mathrm{~h}$ trough IOP (15.9 vs $16.3 \mathrm{~mm} \mathrm{Hg} ; \mathrm{p}=0.041$ ) whereas tafluprost provided significantly lower $24 \mathrm{~h}$ IOP fluctuation ( 3.2 vs $3.8 \mathrm{~mm} \mathrm{Hg} ; \mathrm{p}=0.008$ ). No significant difference existed between the two prostaglandins for any adverse event.

Conclusions PF tafluprost achieved similar $24 \mathrm{~h} \mathrm{IOP}$ reduction to branded latanoprost. The current study highlights the importance of complete assessment of efficacy over $24 \mathrm{~h}$.

Clinical trials registration NCT01162603.

\section{INTRODUCTION}

Prostaglandin analogues have become a popular firstline therapeutic option for the decrease in intraocular pressure (IOP) in patients with open angle glaucoma or ocular hypertension (OHT) due to their superior $24 \mathrm{~h}$ potency, convenient dosing and favourable systemic safety profile. Until recently, all available prostaglandin analogues were formulated as preservative containing solutions. Preservatives used in ophthalmic solutions, and in particular benzalkonium chloride (BAK), have been associated with ocular tissue toxicity and decreased long term tolerability, thus potentially limiting adherence and undermining the success of chronic medical therapy. ${ }^{1-5}$ Long term tolerability has emerged as a key issue for the successful management of glaucoma patients. Furthermore, there is growing recognition that preservatives are associated with ocular surface disease, which negatively impacts on quality of life in glaucoma patients. ${ }^{6}$

Tafluprost $0.0015 \%$ is a relatively new prostaglandin analogue that first became commercially available as a BAK preserved formulation. The first studies indicated that the IOP lowering effect of preserved tafluprost is comparable, or slightly inferior, to that of latanoprost ${ }^{78}$ and travoprost. ${ }^{9}$ More recently, a preservative free $(\mathrm{PF})$ formulation of tafluprost has been made available in several countries worldwide. ${ }^{10-17}$ The comparative efficacy of PF tafluprost versus other prostaglandins needs to be further elucidated in controlled prospective studies.

To date, the $24 \mathrm{~h}$ efficacy of PF tafluprost has not been determined. In order to select the optimal initial monotherapy, it is important to compare the efficacy of all available prostaglandin analogues over $24 \mathrm{~h}$. Therefore, the present investigation evaluated the $24 \mathrm{~h}$ IOP efficacy of PF tafluprost $0.0015 \%$ versus BAK preserved branded latanoprost $0.005 \%$ when both were administered as first choice therapy in patients with primary open angle glaucoma (POAG) or OHT.

\section{MATERIALS AND METHODS}

The research protocol adhered to the tenets of the Declaration of Helsinki and was approved by the institutional review boards of the participating centres. Written informed consent was obtained from all participants prior to enrolment. The trial was registered at clinicaltrials.gov (NCT01162603).

Consecutive adults with newly diagnosed POAG or OHT were recruited at two participating centres. Eligible subjects had to exhibit untreated sitting morning IOP, evaluated with Goldmann tonometry, of $24-33 \mathrm{~mm} \mathrm{Hg}$ in the study eye on two separate baseline IOP measurements performed at time 10:00 ( $\pm 1 \mathrm{~h})$. Additional eligibility criteria were central corneal thickness between 500 and $600 \mu \mathrm{m}$ and age 39-85 years. In each case, the diagnosis of POAG or OHT was made by one of two glaucoma specialists (AGPK or LQ) based on the European 
Glaucoma Society criteria following a comprehensive clinical examination.

Exclusion criteria for ophthalmic conditions were corneal or other anatomical abnormalities preventing reliable applanation tonometry, severe dry eye, use of contact lenses, intolerance or contraindication to latanoprost, tafluprost or BAK, history of poor medication adherence, laser treatment or ocular surgery of any type in the study eye, best corrected visual acuity less than Snellen 0.1 , mean deviation worse than $-12 \mathrm{~dB}$ on Humphrey 24-2 SITA standard perimetry, cup to disc ratio $>0.8$, or the possibility of optic nerve damage and visual function deterioration due to study procedures according to the investigator's judgment. Exclusion criteria for systemic conditions were pregnancy or lactation, unwillingness to avoid pregnancy and use of corticosteroids within the 2 months before enrolment.

\section{Procedures}

The trial was designed as a prospective, randomised, observer masked, active controlled, crossover study. First, eligible participants were admitted at the participating academic centres and underwent baseline untreated $24 \mathrm{~h}$ IOP monitoring in habitual positions, with Goldmann sitting tonometry, at times 10:00, 14:00, 18:00 and 22:00, and Perkins supine tonometry at times 02:00 and 06:00 $( \pm 1 \mathrm{~h})$. In each centre, the same calibrated Goldmann and Perkins tonometers were used for all measurements. In all cases, the investigator who performed the IOP measurements was blinded to the treatment regimen. Following the untreated $24 \mathrm{~h}$ IOP curve, participants were randomised to either 3 months of chronic therapy with preserved latanoprost $0.005 \%$ solution (Xalatan; Pfizer) dosed in the evening (20:00), or to 3 months of therapy with PF tafluprost $0.0015 \%$ solution (Saflutan; MSD) dosed also in the evening (20:00). Both eyes were treated. Instructions regarding correct eyedrop instillation and adherence were also provided. At the end of this initial 3 month treatment period, all participants underwent a treated 24 h IOP assessment, as previously described. Patients were then crossed over to the opposite prostaglandin therapy for another 3 months and instructions regarding correct eyedrop instillation and adherence were repeated. At the end of this final therapy period, participants underwent a third $24 \mathrm{~h}$ IOP curve with identical methodology. A comprehensive clinical examination was performed at all visits. Additionally, patient reported complains and symptoms, as well as investigator noted adverse events, were recorded at the end of each treatment period.

\section{Statistics}

The primary efficacy endpoint for this study was mean $24 \mathrm{~h}$ IOP. Individual time points, peak, trough and fluctuations in 24 h IOP were evaluated as secondary endpoints. The study had $80 \%$ power to identify a $1.25 \mathrm{~mm} \mathrm{Hg}$ difference between individual time points and between the mean 24-h IOP, assuming an SD of $2.8 \mathrm{~mm} \mathrm{Hg}$ between the two prostaglandin monotherapies. One randomly selected eye per participant was analysed. A mixed model was used for the crossover repeated measures design to adjust for period and carryover effects. ${ }^{18}$ Additionally, the model was adjusted for the centre effect. A 95\% CI was constructed for the adjusted difference in means. An intention to treat approach was adopted, and subjects were analysed according to their randomised group.

To correct for multiple comparisons at individual time points, a Bonferroni adjustment was used. Thus Bonferroni adjusted $\mathrm{p}$ values are reported for individual time point comparisons. All other reported $\mathrm{p}$ values are two tailed, with $\mathrm{p}<0.05$ considered significant. Mean $24 \mathrm{~h}$ IOP fluctuation was defined as the

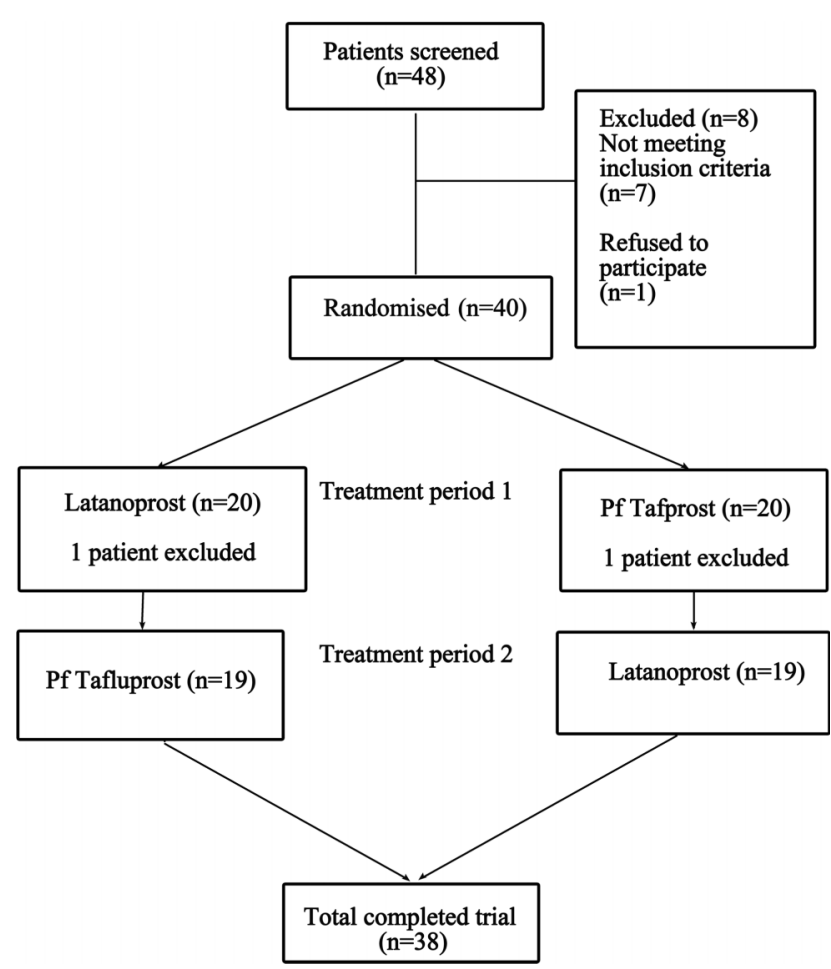

Figure 1 Flowchart of the study participants.

average of the difference between the highest IOP reading minus the lowest IOP reading within the $24 \mathrm{~h}$ curve for each patient. Adverse events were evaluated using a McNemar test. All analyses were conducted using IBM-SPSS 20.0.

\section{RESULTS}

\section{Patients}

Thirty-eight of 40 enrolled participants completed the study. Their flowchart and demographics are presented in figure 1 and table 1. Two study patients (one in each therapy group) were lost to follow-up.

\section{Intraocular pressure}

Compared with untreated baseline readings, mean $24 \mathrm{~h}$, peak, trough, fluctuation and IOP at individual time points were all significantly reduced with both prostaglandin monotherapies ( $\mathrm{p}<0.001$ for all comparisons) (table 2). When the two prostaglandins were directly compared, PF tafluprost demonstrated similar mean $24 \mathrm{~h}$ efficacy compared with preserved latanoprost $(17.8 \pm 2.2$ vs $17.7 \pm 2.1 \mathrm{~mm} \mathrm{Hg} ; \mathrm{p}=0.417)$. Furthermore, there

Table 1 Participant demographics

\begin{tabular}{lc}
\hline Characteristic & \\
\hline Sex (M/F) & $18 / 20$ \\
Age (years) & $66.7(9.1)$ \\
CCT ( $\mu \mathrm{m})$ & $551(24.4)$ \\
Snellen BCVA & $0.8(0.2)$ \\
C/D & $0.6(0.1)$ \\
MD (dB) & $5.41(3.1)$ \\
\hline Values are mean (SD) or number. & \\
BCVA, best corrected visual acuity; CCT, central corneal thickness; C/D, cup/disc ratio; \\
MD, mean deviation.
\end{tabular}


Table 2 Intraocular pressure results at baseline and after treatment with the study medications

\begin{tabular}{|c|c|c|c|c|c|}
\hline IOP measurements (time) & $\begin{array}{l}\text { Baseline } \\
\text { (mean }(95 \% \mathrm{CI}))\end{array}$ & $\begin{array}{l}\text { Latanoprost } \\
(\text { mean }(95 \% \mathrm{Cl}))^{*}\end{array}$ & $\begin{array}{l}\text { PF tafluprost } \\
(\text { mean }(95 \% \mathrm{CI}))^{*}\end{array}$ & Adjusted difference $(\text { mean }(95 \% \mathrm{CI}))^{*}$ & p Value \\
\hline 06:00 & $25.1(24.2$ to 26.0$)$ & $17.5(16.7$ to 18.3$)$ & 17.5 (16.8 to 18.4$)$ & $0.00(-0.44$ to 0.44$)$ & $1.000 t$ \\
\hline $10: 00$ & $26.9(26.1$ to 27.7$)$ & $17.9(17.0$ to 18.8$)$ & $18.4(17.5$ to 19.3$)$ & $-0.50(-1.03$ to 0.03$)$ & $0.372 \dagger$ \\
\hline $14: 00$ & $24.1(23.2$ to 25.0$)$ & 17.3 (16.5 to 18.2$)$ & $17.8(17.0$ to 18.6$)$ & $-0.47(-1.05$ to 0.10$)$ & $0.624 \dagger$ \\
\hline $18: 00$ & 23.8 (23.0 to 24.6$)$ & $17.3(16.4$ to 18.1$)$ & 17.7 (16.8 to 18.5$)$ & $-0.39(-0.88$ to 0.09$)$ & $0.648 t$ \\
\hline $22: 00$ & 24.9 (23.8 to 26.0$)$ & 17.8 (16.9 to 18.8$)$ & 17.6 (16.6 to 18.5$)$ & $0.24(-0.20$ to 0.67$)$ & $1.000 t$ \\
\hline 02:00 & 24.4 (23.6 to 25.2$)$ & $18.0(17.2$ to 18.9$)$ & $17.6(16.8$ to 18.4$)$ & $0.45(-0.07$ to 0.96$)$ & $0.516 t$ \\
\hline Mean $24 \mathrm{~h}$ & $24.9(24.2$ to 25.5$)$ & 17.7 (16.9 to 18.4$)$ & $17.8(17.0$ to 18.5$)$ & $-0.11(-0.39$ to 0.17$)$ & 0.416 \\
\hline Peak $24 \mathrm{~h}$ & 27.7 (26.8 to 28.6) & 19.7 (18.8 to 20.5$)$ & 19.5 (18.6 to 20.3$)$ & $0.24(-0.18$ to 0.66$)$ & 0.277 \\
\hline Trough $24 \mathrm{~h}$ IOP & 18.3 (17.8 to 18.8$)$ & 15.9 (15.2 to 16.6$)$ & $16.3(15.6$ to 17.0$)$ & $-0.39(-0.78$ to -0.01$)$ & 0.041 \\
\hline $24 \mathrm{~h}$ fluctuation & 3.7 (3.4 to 4.0$)$ & 3.8 (3.2 to 4.3$)$ & $3.2(2.6$ to 3.7$)$ & $0.63(0.18$ to 1.08$)$ & 0.008 \\
\hline
\end{tabular}

were no statistically significant differences for individual time points (table 2, figure 2).

With regard to other $24 \mathrm{~h}$ IOP characteristics, PF tafluprost demonstrated significantly lower $24 \mathrm{~h}$ IOP fluctuation $(3.2 \pm 1.7$ vs $3.8 \pm 1.8 \mathrm{~mm} \mathrm{Hg} ; \mathrm{p}=0.008)$. In contrast, latanoprost provided significantly lower $24 \mathrm{~h}$ trough IOP $(15.9 \pm 2.1$ vs 16.3 $\pm 2.2 \mathrm{~mm} \mathrm{Hg} ; \mathrm{p}=0.041$ ). There was no significant difference in $24 \mathrm{~h}$ peak IOP between the two prostaglandins (19.7 vs $19.5 \mathrm{~mm} \mathrm{Hg}$, respectively; $\mathrm{p}=0.277$ ) (table 2 ).

\section{Adverse events}

No serious adverse events and no adverse event related withdrawal occurred during the study. In addition, there was no significant difference between the two agents for any adverse event

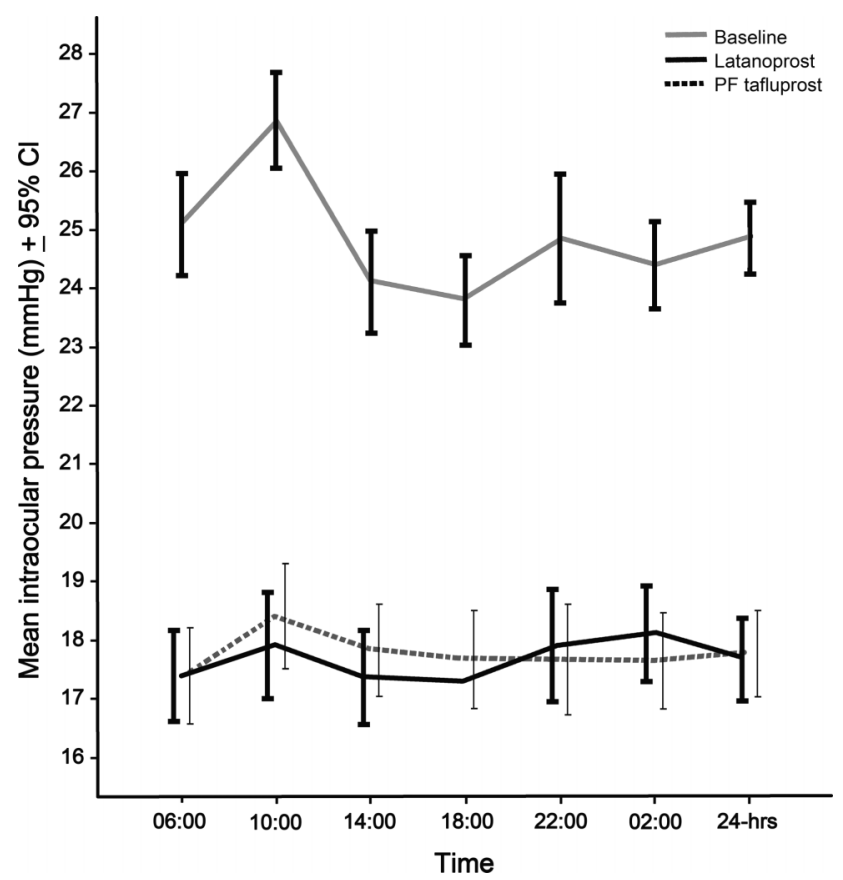

Figure 2 Intraocular pressure (mean $\pm 95 \% \mathrm{Cl}$ ) at each individual time point and for the $24 \mathrm{~h}$ pressure at baseline (gray solid line), in the latanoprost (solid black line) and preservative free (Pf) tafluprost (black dotted line) treatment groups. (table 3). Overall, the number of adverse events with latanoprost and PF tafluprost treatment were 22 and 14, respectively. The most frequently encountered adverse event was ocular hyperaemia ( $\mathrm{n}=6$ during latanoprost treatment period; $\mathrm{n}=5$ during PF tafluprost treatment period).

\section{DISCUSSION}

The present study is the first to evaluate the $24 \mathrm{~h}$ efficacy of PF tafluprost compared with branded preserved latanoprost as a first choice monotherapy in newly diagnosed patients with POAG or OHT. The results showed identical mean IOP lowering over $24 \mathrm{~h}$ (mean $24 \mathrm{~h}$ IOP difference was only $0.1 \mathrm{~mm} \mathrm{Hg}$ ). Greater $24 \mathrm{~h}$ trough IOP reduction was observed during latanoprost therapy while significantly lower $24 \mathrm{~h}$ IOP fluctuation was documented with PF tafluprost.

Tafluprost, a fluorinated analogue of prostaglandin $F_{2 a}$, is a potent and selective agonist of the human prostanoid FP receptor with a reported 12 fold greater affinity for the FP receptor than latanoprost. ${ }^{19}$ It was first introduced in Japan in 2008 as a BAK containing multidose formulation, and in Germany in 2008 with approval for both a preserved and a PF tafluprost formulation. ${ }^{20}{ }^{21}$ Currently, however, throughout the rest of the world, only the PF formulation is marketed. ${ }^{20}{ }^{21}$ Initial reports in healthy eyes indicated that preserved tafluprost was at least as well tolerated and safe as preserved latanoprost when used over short periods. ${ }^{22-25}$ Furthermore, it was demonstrated that the efficacy of preserved tafluprost was comparable with that of preserved latanoprost in healthy volunteers. ${ }^{22-26}$

Due to its short marketing history, there are limited long term efficacy data for preservative containing tafluprost in patients with glaucoma or OHT. Two studies have reported that preserved tafluprost attained a mean diurnal IOP reduction of $28.6 \%$ and $29.1 \%$, respectively, from untreated baseline. ${ }^{8} 9 \mathrm{~A}$ third short term phase II study ${ }^{7}$ reported that the mean IOP change from baseline of preserved tafluprost was similar to that of branded latanoprost after 42 days $(-9.7 \mathrm{~mm} \mathrm{Hg}$ for tafluprost and $-8.8 \mathrm{~mm} \mathrm{Hg}$ for latanoprost). In a 24 month, parallel, double blind, multicenter study performed by Uusitalo et al, ${ }^{8}$ tafluprost lowered daytime IOP by $6-8 \mathrm{~mm} \mathrm{Hg}(27-31 \%)$ compared with 7-9 $\mathrm{mm} \mathrm{Hg}(29-35 \%)$ with branded latanoprost. In this study, after 24 months of therapy, the mean decrease in IOP from baseline was reported to be somewhat superior with latanoprost $(-7.7 \mathrm{~mm} \mathrm{Hg}, \quad 32.2 \%)$ than preserved tafluprost 
Table 3 Adverse events of the study medications

\begin{tabular}{|c|c|c|c|c|c|}
\hline \multirow[b]{2}{*}{ Adverse event } & \multirow[b]{2}{*}{ Latanoprost } & \multicolumn{2}{|c|}{ PF tafluprost } & \multirow{2}{*}{$\begin{array}{l}\text { n (\%) } \\
\text { Total }\end{array}$} & \multirow[b]{2}{*}{$\mathrm{p}$ Value } \\
\hline & & Yes & No & & \\
\hline \multirow[t]{2}{*}{ Ocular hyperaemia } & Yes & 2 & 4 & $6(15.8)$ & 1.000 \\
\hline & No & 3 & 29 & $32(84.2)$ & \\
\hline n (\%) & Total & $5(13.2)$ & $33(87.8)$ & $38(100)$ & \\
\hline \multirow[t]{2}{*}{ Stinging } & Yes & 1 & 3 & $4(10.5)$ & 1.000 \\
\hline & No & 3 & 31 & $34(89.5)$ & \\
\hline $\mathrm{n}(\%)$ & Total & $4(10.5)$ & $34(89.5)$ & $38(100)$ & \\
\hline \multirow[t]{2}{*}{ Foreign body sensation } & Yes & 0 & 2 & $2(5.3)$ & 1.000 \\
\hline & No & 2 & 34 & $36(94.7)$ & \\
\hline $\mathrm{n}(\%)$ & Total & $2(5.3)$ & $36(94.7)$ & $38(100)$ & \\
\hline \multirow[t]{2}{*}{ Blurring of vision } & Yes & 1 & 3 & $4(10.5)$ & 0.250 \\
\hline & No & 0 & 34 & $34(89.5)$ & \\
\hline $\mathrm{n}(\%)$ & Total & $1(2.6)$ & 37 (97.4) & $38(100)$ & \\
\hline \multirow[t]{2}{*}{ Watering } & Yes & 1 & 1 & $2(5.3)$ & 1.000 \\
\hline & No & 0 & 36 & $36(94.7)$ & \\
\hline $\mathrm{n}(\%)$ & Total & $1(2.6)$ & 37 (97.4) & $38(100)$ & \\
\hline \multirow[t]{2}{*}{ Itchiness } & Yes & 0 & 2 & $2(5.3)$ & 0.500 \\
\hline & No & 0 & 36 & $36(94.7)$ & \\
\hline n (\%) & Total & $0(0)$ & $38(100)$ & $38(100)$ & \\
\hline \multirow[t]{2}{*}{ Burning } & Yes & 0 & 2 & $2(5.3)$ & 0.500 \\
\hline & No & 0 & 36 & $36(94.7)$ & \\
\hline n (\%) & Total & $0(0)$ & $38(100)$ & $38(100)$ & \\
\hline \multirow[t]{2}{*}{ Ocular ache } & Yes & 0 & 0 & $0(0)$ & 1.000 \\
\hline & No & 1 & 37 & $38(100)$ & \\
\hline $\mathrm{n}(\%)$ & Total & $1(2.6)$ & 37 (97.4) & 38 (100) & \\
\hline
\end{tabular}

$\mathrm{PF}$, preservative free.

(-7.1 mm Hg, 29.1\%). ${ }^{8}$ This study demonstrated that the noninferiority criterion for tafluprost was reached with ANOVA and almost reached with ANCOVA for all daytime IOP measurements.

There is convincing evidence suggesting that PF tafluprost exhibits comparable efficacy to preserved tafluprost. First, a pharmacokinetic study ${ }^{27}$ did not detect a difference in systemic bioavailability between the two formulations after 8 days. Second, Hamacher et al ${ }^{10}$ evaluated the IOP lowering equivalency between the two formulations and observed an overall efficacy difference of only $0.01 \mathrm{~mm} \mathrm{Hg}(95 \% \mathrm{CI}-0.46$ to 0.49 ; $\mathrm{p}=0.96)$ at 4 weeks.

Several open label non-interventional studies have examined the efficacy and tolerability of PF tafluprost in naïve ${ }^{16}$ or previously treated patients with open angle glaucoma or OHT, who were either poorly controlled or had tolerability issues with other medications. ${ }^{12-15} 28$ Overall, these investigations have reported a mean diurnal IOP reduction of $22.9-32.1 \%$ from untreated baseline. ${ }^{13} \quad 16 \quad 28$ Although these studies do not provide controlled observations, they indicate that PF tafluprost has almost comparable efficacy to latanoprost and will likely benefit patients facing tolerability problems with other medications. Similar IOP results were reported in a prospective investigator masked study. ${ }^{29}$ In a more recent regulatory double masked comparative trial, Chabi et al ${ }^{11}$ demonstrated in patients with open angle glaucoma or OHT that PF tafluprost was generally well tolerated and was not inferior to PF timolol administered twice daily.

The current trial investigated for the first time the $24 \mathrm{~h}$ IOP efficacy provided by a PF tafluprost versus branded latanoprost, a well established initial therapy of choice. Both agents provided clinically meaningful $24 \mathrm{~h}$ IOP reduction from baseline $(28.5 \%$ for PF tafluprost and $29.3 \%$ for latanoprost). These results are comparable with the reported $24 \mathrm{~h}$ efficacy of the three previously available prostaglandin analogues, as reported in a meta-analysis by Stewart et al (24-29\%). ${ }^{30}$ A 24 h IOP curve may better delineate IOP characteristics and facilitate glaucoma management. Thus our study provides evidence to optimise selection between available prostaglandin analogues as initial therapy.

This efficacy profile would not have been detected without a complete $24 \mathrm{~h}$ IOP evaluation. Thus the present study highlights the value of a complete efficacy assessment over $24 \mathrm{~h}$ in determining the true IOP lowering characteristics of a novel antiglaucoma medication. In a previous $24 \mathrm{~h}$ IOP study in 30 healthy Japanese subjects, Mochizuki et al compared the efficacy of tafluprost and branded latanoprost. ${ }^{25}$ Apart from the differences in study populations and despite several methodological differences (timing of drug administration, duration of therapy and different time of IOP measurements), it is interesting to note the similarities in findings between the two $24 \mathrm{~h}$ studies. The Mochizuki study ${ }^{25}$ also observed a mean $24 \mathrm{~h}$ difference of $0.1 \mathrm{~mm} \mathrm{Hg}$ and the two prostaglandins exhibited similar tendencies to preferentially lower IOP during the day (latanoprost) and night (tafluprost). In contrast with the present study, however, these IOP lowering differences reached statistical significance in the Japanese study.

In the present study, PF tafluprost achieved significantly less $24 \mathrm{~h}$ IOP fluctuation than branded latanoprost. Twenty-four hour IOP fluctuation and $24 \mathrm{~h}$ peak IOP have emerged in some $24 \mathrm{~h}$ studies $^{31-33}$ as potential risk factors for glaucoma progression. This has brought attention to the $24 \mathrm{~h}$ IOP lowering 
profiles with topical medications. ${ }^{34} 35$ Based on the notion that increased circadian IOP fluctuation may be harmful for some glaucoma patients, it may be clinically desirable to opt for favourable 24 h IOP characteristics, such as low 24 h IOP fluctuation and low $24 \mathrm{~h}$ peak IOP. However, the potential long term clinical benefit of improved $24 \mathrm{~h}$ IOP control requires further elucidation.

The current study was a short term monotherapy study and it did not have sufficient power to determine long term safety or tolerability. Both medications were well tolerated without serious adverse events or adverse event related study withdrawals. There was no significant difference in the incidence of individual adverse events. Nevertheless, the adverse events observed in our trial may not accurately portray the true long term tolerability profile of these agents.

Glaucoma requires lifelong treatment and thus long term tolerability is an issue of clinical importance. Cumulative evidence shows that long term topical treatment with antiglaucoma medications leads to the manifestation, or exacerbation, of symptoms and signs of ocular surface disease. ${ }^{3}{ }^{36}$ As a consequence, patient's quality of life can decline and adherence may be adversely affected. ${ }^{37-42}$ There is convincing evidence that long term exposure to preservatives, and especially BAK, can cause histopathological changes in ocular tissues that can adversely affect the success of subsequent glaucoma surgery. ${ }^{4} \mathrm{PF}$ medications have become increasingly popular in glaucoma due to their reduced potential for ocular toxicity with presumed enhanced tolerability and improved adherence. ${ }^{384344}$ The observation of similar drug efficacy versus available preservative containing treatment options may encourage greater use of PF medications. On the other hand, more evidence is needed to confirm the long term potential benefits accrued with the use of PF medications, such as improved medication adherence leading to better long term visual outcomes. By demonstrating comparable $24 \mathrm{~h}$ efficacy to branded latanoprost, PF tafluprost can be considered as a reasonable firstline choice in glaucoma therapy.

Contributors The study was designed by AGPK and LQ. Data collection was performed by IR, A-BH, TG, ICV and EP. Data analysis and interpretation was performed by IF, A-BH, AGPK and LQ. The manuscript was drafted by AGPK, AK and IR. Critical revision of the manuscript was done by AGPK, LQ and JCT. All authors read and approved the final version of the article.

Competing interests AGPK is a consultant for Alcon, Allergan, MSD and Nicox. AGPK has received honoraria or travel reimbursement from Alcon, Allergan and Pfizer. LQ has received honoraria or travel reimbursement from Alcon, Allergan, MSD, Thea Farmila, and Bausch and Lomb. AK has received travel reimbursement from Alcon and MSD. IR has received travel reimbursement from Alcon and MSD.

Ethics approval The study was approved by the institutional review board of the Medical School of Aristotle University, Thessaloniki, Greece, and the institutional review board of the Clinica Oculistica, University of Brescia, Brescia, Italy.

Provenance and peer review Not commissioned; externally peer reviewed.

\section{REFERENCES}

1 Ammar AD, Kahook YM. Effects of benzalconium chloride- or polyquad-preserved fixed combination glaucoma medications on human trabecular meshwork cells. $\mathrm{Mol}$ Vis 2011;17:1806-13.

2 Baudouin C, Labbé A, Liang $\mathrm{H}$, et al. Preservatives in eyedrops: the good, the bad and the ugly. Prog Retin Eye Res 2010;29:312-34.

3 Baudouin C, Pisella PJ, Goldschild M, et al. Ocular surface inflammatory changes induced by topical antiglaucoma drugs: human and animal studies. Ophthalmology 1999:106:556-63.

4 Broadway DC, Grierson I, O'Brien C, et al. Adverse effects of topical antiglaucoma medication. II. The outcome of filtration surgery. Arch Ophthalmol 1994; 112:1446-54

5 Lavin MJ, Wormald RP, Migdal CS, et al. The influence of prior therapy on the success of trabeculectomy. Arch Ophthalmol 1990;108:1543-8.

6 Skalicky SE, Goldberg I, McCluskey P. Ocular surface disease and quality of life in patients with glaucoma. Am J Ophthalmol 2012:153:1-9.
7 Traverso CE, Ropo A, Papadia M, et al. A phase II study on the duration and stability of the intraocular pressure-lowering effect and tolerability of tafluprost compared with latanoprost. J Ocul Pharmacol Ther 2010:26:97-104.

8 Uusitalo H, Pillunat LE, Ropo A. Efficacy and safety of tafluprost $0.0015 \%$ versus latanoprost $0.005 \%$ eye drops in open-angle glaucoma and ocular hypertension: 24 -month results of a randomized, double-masked phase III study. Acta Ophthalmol 2010;88:12-19.

9 Schnober D, Hofmann G, Maier H, et al. Diurnal IOP-lowering efficacy and safety of travoprost $0.004 \%$ compared with tafluprost $0.0015 \%$ in patients with primary open-angle glaucoma or ocular hypertension. Clin Ophthalmol 2010;4:1459-63.

10 Hamacher T, Airaksinen J, Saarela V, et al. Efficacy and safety levels of preserved and preservative-free tafluprost are equivalent in patients with glaucoma or ocular hypertension: results from a pharmacodynamics analysis. Acta Ophthalmol 2008;86 (Suppl 242):14-19.

11 Chabi A, Varma R, Tsai JC, et al. Randomized clinical trial on the efficacy and safety of preservative-free tafluprost and timolol in patients with open-angle glaucoma or ocular hypertension. Am J Ophthalmol 2012;153:1187-96.

12 Uusitalo $\mathrm{H}$, Chen $\mathrm{E}$, Pfeiffer $\mathrm{N}$, et al. Switching from a preserved to a preservative-free prostaglandin preparation in topical glaucoma medication. Acta Ophthalmol 2010;88:329-36.

13 Hommer A, Ramez OM, Burchert M, et al. IOP-lowering efficacy and tolerability of preservative-free tafluprost $0.0015 \%$ among patients with ocular hypertension or glaucoma. Curr Med Res Opin 2010;26:1905-13.

14 Hommer A, Kimmich F. Switching patients from preserved prostaglandin-analog monotherapy to preservative-free tafluprost. Clin Ophthalmol 2011;5:623-31.

15 Erb C, Lanzl I, Seidova S-F, et al. Preservative-free Tafluprost $0.0015 \%$ in the treatment of patients with glaucoma and ocular hypertension. Adv Ther 2011;28:575-85.

16 Rossi GCM, Pasinetti GM, Raimondi M, et al. Efficacy and ocular surface tolerability of preservative-free tafluprost $0.0015 \%$ : a 6-month, single-blind, observational study on naïve ocular hypertension or glaucoma patients. Expert Opin Drug Saf 2012;11:519-25.

17 Ranno S, Mateo S, Cinzia B, et al. A prospective study evaluating IOP changes after switching from a therapy with prostaglandin eye drops containing preservatives to non-preserved Tafluprost in glaucoma patients. Scientific World J 2012;804730. http://www.ncbi.nlm.nih.gov/pmc/articles/PMC3346840 (accessed 18 Dec 2012).

18 Senn S. Cross-over trials in clinical research. 2nd edn. Chichester: Wiley, 2002.

19 Takagi Y, Nakajima T, Shimazaki A, et al. Pharmacological characteristics of AFP-168 (tafluprost), a new prostanoid FP receptor agonist, as an ocular hypotensive drug. Exp Eye Res 2004;78:767-76.

20 Aihara M. Clinical appraisal of tafluprost in the reduction of elevated intraocular pressure (IOP) in open-angle glaucoma and ocular hypertension. Clin Ophthalmol 2010;4:163-70.

21 Pantcheva MB, Seibold LK, Awadallah NS, et al. Tafluprost: a novel prostaglandin analog for treatment of glaucoma. Adv Ther 2011;28:707-15.

22 Sutton A, Gilvarry A, Ropo A. A comparative, placebo-controlled study of prostanoid fluoroprostaglandin-receptor agonists tafluprost and latanoprost in healthy males. J Ocul Pharm Ther 2007;23:359-65.

23 Sutton A, Gouws P, Ropo A. Tafluprost, a new potent prostanoid receptor agonist: a dose-response study on pharmacodynamics and tolerability in healthy volunteers. Int J Clin Pharm Ther 2008;46:400-6.

24 Uusitalo H, Kaamiranta K, Ropo A. Pharmacokinetics, efficacy and safety profiles of preserved and preservative-free tafluprost in healthy volunteers. Acta Ophthalmol 2008;86(Suppl 242):7-13.

25 Mochizuki H, Itakura H, Yokoyama T, et al. Twenty-four-hour ocular hypotensive effects of $0.0015 \%$ tafluprost and $0.005 \%$ latanoprost in healthy subjects. Jpn J Ophthalmol 2010;54:286-90.

26 Kawaguchi I, Higashide T, Ohkubo S, et al. Comparison of efficacy of four prostaglandin analogues by bilateral treatment in healthy subjects. Jpn J Ophthalmol 2012;56:346-53

27 SAFLUTAN (tafluprost), Summary of product characteristics, date of revision: 16 March 2011. http://www.medicines.org.uk/EMC/medicine/22237/SPC/SAFLUTAN+15 +micrograms+ml+eye+drops $\% 2 c+$ solution $\% 2 c+$ single-dose+container/ (accessed 18 Dec 2012).

28 Milla E, Stirbu 0, Rey A, et al. Spanish multicenter tafluprost tolerability study. $\mathrm{Br} J$ Ophthalmol 2012;96:826-31.

29 Januleviciene I, Derkac I, Grybauskiene L, et al. Effects of preservative-free tafluprost on tear film osmolarity, tolerability and intraocular pressure in previously treated patients with open-angle glaucoma. Clin Ophthalmol 2012;6:103-9.

30 Stewart WC, Konstas AGP, Nelson LA, et al. Meta-analysis of 24-hour intraocular pressure studies evaluating the efficacy of glaucoma medicines. Ophthalmology 2008:115:1117-22.

31 Asrani S, Zeimer R, Wilensky J, et al. Large diurnal fluctuations in intraocular pressure are an independent risk factor in patients with glaucoma. J Glaucoma 2000;9:134-42.

32 Barkana Y, Anis S, Liebmann J, et al. Clinical utility of intraocular pressure monitoring outside of normal office hours in patients with glaucoma. Arch Ophthalmol 2006;124:793-97.

33 Konstas AG, Quaranta L, Mikropoulos DG, et al. Peak intraocular pressure and glaucomatous progression in primary open-angle glaucoma. J Ocul Pharmacol Ther 2012:28:26-32. 


\section{Downloaded from bjo.bmj.com on May 16, 2013 - Published by group.bmj.com}

\section{Clinical science}

34 Konstas AG, Quaranta L, Realini T. Overview of the BAK-free travoprost/timolol fixed combination. Expert Opin Pharmacother 2012;13:757-66.

35 Quaranta L, Katsanos A, Russo A, et al. 24-hour intraocular pressure and ocular perfusion pressure in glaucoma. Surv Ophthalmol 2013;58:26-41.

36 Leung EW, Medeiros FA, Weinreb RN. Prevalence of ocular surface disease in glaucoma patients. J Glaucoma 2008;17:350-55.

37 Feldman RM. Conjunctival hyperemia and the use of topical prostaglandins in glaucoma and ocular hypertension. J Ocul Pharmacol Ther 2003;19:23-35.

38 Reardon G, Schwartz GF, Mozaffari E. Patient persistency with ocular prostaglandin therapy: a population-based, retrospective study. Clin Ther 2003;25:1172-85.

39 Baudouin C, Renard J-P, Nordmann J-P, et al. Prevalence and risk factors for ocular surface disease among patients treated over the long term for glaucoma or ocular hypertension. Eur J Ophthalmol 2013;23:47-54.
40 Nordmann JP, Auzanneau N, Ricard S, et al. Vision related quality of life and topical glaucoma treatment side effects. Health Qual Life Outcomes 2003;1:75.

41 Rossi GC, Tinelli C, Pasinetti GM, et al. Dry eye syndrome-related quality of life in glaucoma patients. Eur J Ophthalmol 2009;19:572-9.

42 Fechtner RD, Godfrey DG, Budenz D, et al. Prevalence of ocular surface complaints in patients with glaucoma using topical intraocular pressure- lowering medications. Cornea 2010;29:618-21

43 Pisella PJ, Pouliquen P, Baudouin C. Prevalence of ocular symptoms and signs with preserved and preservative-free glaucoma medication. $\mathrm{Br} J$ Ophthalmol 2002:86:418-23.

44 Jaenen N, Baudouin C, Pouliquen P, et al. Ocular symptoms and signs with preserved and preservative-free glaucoma medications. Eur J Ophthalmol 2007;17:341-49. 


\section{BJO}

\section{Twenty-four hour efficacy with preservative free tafluprost compared with latanoprost in patients with primary open angle glaucoma or ocular hypertension}

Anastasios G P Konstas, Luciano Quaranta, Andreas Katsanos, et al.

Br J Ophthalmo/ published online May 16, 2013

doi: 10.1136/bjophthalmol-2012-303026

Updated information and services can be found at:

http://bjo.bmj.com/content/early/2013/05/14/bjophthalmol-2012-303026.full.html

\section{These include:}

References This article cites 41 articles, 2 of which can be accessed free at: http://bjo.bmj.com/content/early/2013/05/14/bjophthalmol-2012-303026.full.html\#ref-list-1

$\mathbf{P}<\mathbf{P} \quad$ Published online May 16, 2013 in advance of the print journal.

Email alerting Receive free email alerts when new articles cite this article. Sign up in service the box at the top right corner of the online article.

Notes

Advance online articles have been peer reviewed, accepted for publication, edited and typeset, but have not not yet appeared in the paper journal. Advance online articles are citable and establish publication priority; they are indexed by PubMed from initial publication. Citations to Advance online articles must include the digital object identifier (DOIs) and date of initial publication.

To request permissions go to:

http://group.bmj.com/group/rights-licensing/permissions

To order reprints go to:

http://journals.bmj.com/cgi/reprintform

To subscribe to BMJ go to:

http://group.bmj.com/subscribe/ 